\title{
ECOLOGY
}

\section{ВИЗНАЧЕННЯ ЕКОЛОГТЧНИХ НОРМАТИВІВ ДЛЯ БАСЕЙНУ РІЧКИ УДИ В МЕЖАХ ХАРКІВСЬКОЇ ОБЛАСТІ}

\author{
канд. техн. наук Рибалова О. В. ${ }^{l}$, \\ канд. біол. наук Ільӥнський О. В. ${ }^{\prime}$, \\ Бондаренко О. О. ${ }^{1}$, \\ Макаров . O. $^{1}$, \\ Жук В. M. ${ }^{2}$ \\ Україна, м. Харків, \\ ${ }^{1}$ Національний університет ичивільного захисту Украӥни, \\ ${ }^{2}$ Басейнова рада Сіверського Діния та Нижнього Дону \\ DOI: https://doi.org/ 10.31435/rsglobal_ws/31012019/6296
}

\section{ARTICLE INFO}

Received: 12 November 2018

Accepted: 22 January 2019

Published: 31 January 2019

\section{KEYWORDS}

ecological condition, ecological norms, forecast, river Udy river basin, Kharkiv region

\begin{abstract}
The article improves the method of establishing ecological norms of surface water quality in accordance with Ukrainian legislation and the Water Framework Directive of the European Union, which represents the scientific novelty of work. For the first time environmental norms for water flows of the Udy river basin have been determined on the basis of the forecast of their qualitative condition, taking into account the landscape-geographic features of the functioning of aquatic ecosystems. Ranking of the observation posts for the quality status of the Udy River in terms of the ecological index value for the permissible and target ecological standard makes it possible to identify the most polluted watercourses. The improvement of the methodology for establishing ecological norms of surface water quality has a purpose to introduce an iterative approach to the management of surface water quality into the water protection practice of Ukraine and its adaptation to the environmental legislation of the EU countries.
\end{abstract}

Citation: Рибалова О. В., Ільїнський О. В., БондаренкоО.О., Макаров С. О., Жук В. М. (2019) Vyznachennia Ekolohichnykh Normatyviv dlia Baseinu Richky Udy v Mezhakh Kharkivskoi Oblasti. World Science. 1(41), Vol.1. doi: 10.31435/rsglobal_ws/31012019/6296

Copyright: (c) 2019 Рибалова О. В., Ільїнський О. В., Бондаренко О. О., Макаров С. О., Жук В. М. This is an open-access article distributed under the terms of the Creative Commons Attribution License (CC BY). The use, distribution or reproduction in other forums is permitted, provided the original author(s) or licensor are credited and that the original publication in this journal is cited, in accordance with accepted academic practice. No use, distribution or reproduction is permitted which does not comply with these terms.

Вступ. Необхідність наукового обгрунтування допустимої межі антропогенного впливу на стан навколишнього природного середовища, зокрема на якісний стан поверхневих вод обумовлює актуальність розробки та впровадження системи екологічних нормативів 3 метою підвищення екологічної безпеки і раціонального використання природних ресурсів.

Сучасна практика встановлення екологічних нормативів стану навколишнього природного середовища та антропогенного навантаження на нього базується на статті 33 Закону України “Про охорону навколишнього природного середовища” [1], яка зобов”язує дотримання вимог санітарно-гігієнічних та санітарно-протиепідемічних правил i норм, гігієнічних нормативів, але не враховує дослідження ландшафтно-географічних особливостей природних екосистем на основі всебічного аналізу взаємозв'язків всіх компонентів 
ландшафтних комплексів у цілому, врахування їх генезису та властивостей, закономірностей формування та змін під впливом природних та антропогенних факторів.

Басейн p. Уди має транскордонне значення i протікає територією великого індустріального центру України, який характеризується високим антропогенним навантаженням. Тому наукове обгрунтування екологічних нормативів якості поверхневих вод басейну річки Уди в Харківській області є дуже актуальним завданням.

Методи дослідження. Вимога до встановлення екологічних нормативів стану навколишнього природного середовища й антропогенних навантажень викладено в статті 33 Закону України “ Про охорону навколишнього природного середовища” [1].

Статті 35 і 37 Водного Кодексу України [2] також передбачають встановлення екологічних нормативів якості водних об'єктів. У той же час методика встановлення цих нормативів дотепер не затверджена. Основні положення методики встановлення екологічних нормативів якості поверхневих вод базуються на основних принципах і положеннях Концепції екологічного нормування [3], Водного кодексу України [2], Водної Рамкової Директиви Європейського Союзу [4] i рекомендаціях міжнародної організації співробітництва й економічного розвитку для країн Східної Європи, Кавказу й Центральної Азії (ВЕКЦА) [5].

Система екологічного нормування повинна забезпечити нормативну основу досягнення балансу між рівнями шкідливого впливу на навколишнє середовище і його здатностями до відновлення [6-9].

При розробці екологічних нормативів необхідно застосовувати ландшафтноекологічний підхід, що враховує географічне положення, динаміку формування й функціонування природних систем, їх різноманітність і одночасно індивідуальну унікальність, стійкість до кліматичних змін, природних і антропогенних впливів і т.п. [6-9].

Розробка екологічних нормативів для водних об’єктів має за мету удосконалення водоохоронної діяльності при збереженні благополуччя водної екосистеми. Екологічні нормативи встановлюють на підставі аналізу результатів обробки матеріалів попередніх гідрологічних, гідрохімічних, гідробіологічних, еколого-токсикологічних і радіоекологічних експедиційних досліджень і режимних спостережень. У цьому полягає принципова відмінність екологічних нормативів якості поверхневих вод від нормативів безпеки водокористування гранично-допустимих концентрацій (ГДК) окремих шкідливих речовин [6].

У роботі [10] на основі аналізу досвіду управління водними ресурсами в Україні й за кордоном сформульовані основні принципи впровадження в Україні комплексного планування й екологічного управління в області використання, охорони й відновлення водних ресурсів. Наведено приклади практичного застосування методики комплексної оцінки й екологічного нормування якості поверхневих вод як основи екологічного менеджменту на прикладі басейну р. Тетерів.

Вперше екологічні нормативи якості води відповідно до Концепції [3] були встановлені для р. Тетерів [10] i p. Рось [11]. Основою визначення екологічних нормативів якості води була обрана екологічна класифікація якості поверхневих вод [12]. Але екологічні нормативи якості води р. Рось і р. Тетерів встановлені без науково-обгрунтованої методики їх визначення.

В роботах $[8,9]$ представлено методику визначення екологічних нормативів якості поверхневих вод і відповідно до цього методу встановлено екологічні нормативи для річки Оскіл. Розроблено екологічні нормативи допустимі (ЕНд), перевищення яких призведе порушення стійкості водної екосистеми, й екологічні нормативи цільові (ЕНц) як перспективні, на досягнення яких повинна орієнтуватися водоохоронна стратегія.

Запропоновано встановлювати екологічні нормативи допустимі (ЕНд) і цільові (ЕНц) окремо для конкретних водних об'єктів на підставі обробки багаторічних даних спостережень за гідрологічними, гідрохімічними і гідробіологічними даними з визначенням екологічного індексу згідно з удосконаленою методикою екологічної оцінки якості поверхневих вод за відповідними категоріями [13], з урахуванням прогнозних моделей [8,9].

Необхідно відзначити, що методику екологічної оцінки якості поверхневих вод за відповідними категоріями [13] розроблено з урахуванням вимог Водної Рамкової Директиви Свропейського Союзу [4], але вона досі не затверджена. Визначення екологічного стану поверхневих вод відповідно до методики [13] вимагає обробку і аналіз великої кількості гідробіологічних даних, що в сучасних умовах проведення моніторингу якості поверхневих вод в Україні практично нереально. Оскільки ми вважаємо встановлення екологічних нормативів для водних об'єктів з урахуванням їх ландшафтно-географічних особливостей конче необхідним, то пропонуємо в разі відсутності гідробіологічних і гідроморфологічних даних брати за основу методику екологічної оцінки якості поверхневих вод за відповідними категоріями [12]. 
Пропонуємо вдосконалити методику визначення екологічних нормативів якості поверхневих вод, яка представлена в роботах [8,9]. Встановлення значень екологічних нормативів (ЕН) для конкретного водного об'єкта складається із наступних етапів:

1) збір, обробка, аналіз вихідних даних і усереднення величин кожного показника екологічного стану водного об'єкта за обраний період часу;

2) побудова бази даних щодо якісного стану водного об'єкту за період більше 20 останніх років;

3) оцінка середнього i максимального екологічного індексу $\left(\mathrm{I}_{\mathrm{E}}\right)$ за відповідними категоріями за окремими показниками якісного стану водного об'єкту за методикою [12] або в разі наявності гідробіологічних і гідроморфологічних даних за методикою [13];

4) аналіз динаміки змін середнього і максимального екологічного індексу за обраний період спостереження для водного об'єкту 3 метою визначення опорних періодів для встановлення екологічних нормативів 3 мінімальними значеннями екологічного індексу $\left(\mathrm{I}_{\mathrm{E}}\right)$;

5) побудова прогнозної моделі екологічного стану водного об'єкту по кожному досліджуваному показнику на період від 15 до 25 років;

6) встановлення значень допустимих екологічних нормативів (ЕНд) для окремих показників якості води на основі визначення середнього значення даних показників з ряду спостережень в обрані опорні періоди, сучасних значень і їх прогнозних величин.

7) встановлення значень цільових екологічних нормативів (ЕНц) для окремих показників якості води на основі визначення мінімальних значень даних показників з ряду спостережень в обрані опорні періоди, сучасних значень і їх прогнозних величин.

Для побудови прогнозних моделей екологічного стану водних об’єктів пропонуємо використовувати метод Хольта-Уінтерса. Цей метод успішно розраховує як середньострокові, так і довгострокові прогнози, оскільки він здатний визначати мікротренди (тренди, які відносяться до коротких періодів) у періоди часу, що безпосередньо передують прогнозним, i екстраполювати ці тренди на майбутнє [14].

Використання прогнозних значень необхідно для уточнення значень екологічного нормативу, а також для правильного планування водогосподарської діяльності, у тому числі й розробки науково-обгрунтованих природоохоронних заходів.

Встановлення значень ЕНд для окремих показників якості поверхневих вод проводиться на основі фактичних значень окремих показників в обрані опорні періоди, з урахуванням прогнозних величин. При цьому відбираються не менше 3-х років із усього ряду років спостережень і один рік 3 останніх 5 років ряду спостережень 3 найкращими показниками екологічного індексу ( $\left.\mathrm{I}_{\mathrm{E}}\right)$. Таким чином, екологічний норматив допустимий (ЕНд) представляє собою середньоарифметичне значення між перерахованими значеннями для кожного показника.

3 метою визначення основних показників погіршення екологічного стану водного об'єкта кожному значенню ЕНд привласнюються відповідні категорії якості поверхневих вод відповідно до методики [12] або методики [13].

Встановлення значень ЕНц для окремих показників якості води проводиться аналогічно визначенню ЕНд. Але значення цільового екологічного нормативу (ЕНц) відповідає мінімальним значенням показників з діапазону обраних даних.

Результати дослідження. Басейн р. Уди $є$ однією 3 найбільших приток річки Сіверський Донець та має транскордонний характер. Загальна довжина річки - 164 км, з них 127 км протікає територією Харківської області. Загальна площа водозбору - 3894 км², 3 них

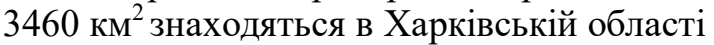

Пост спостереження за якісним станом р. Уди в с. Окоп розташовано на кордоні 3 Російською Федерацією. Це транскордонна ділянка річки Уди. Річка вузька, ширина на перекатах 3-5 м, на плесах до $7-8$ м. Течія досить швидка, глибина 0,6-1,0 м. Уздовж русла розвинені смуги деревної й чагарникової гігрофільної рослинності. Дно на перекатах круте, на плесах - більше пологе. Грунт мулистий 3 великою кількістю рослинного детриту. Безпосередньо в районі відбору проб біля річки немає житлових будівель, примикають сільгоспугіддя, головним чином сіножаті [15].

Відповідно до методики [12] визначено середній і максимальний екологічний індекс для річки Уди в с. Окоп за період з 2000 року по 2017 рік. Значення середнього екологічного індексу для річки Уди в с. Окоп за період з 2000 року по 2017 рік відповідає 3 категорії і 2 класу якості (гарний стан). Значення максимального екологічного індексу для річки Уди в с. Окоп за період з 2000 року по 2017 рік відповідає 5 категорії (незадовільний стан) і 3 класу якості (задовільний стан). 
Прогноз екологічного стану р. Уди в с. Окоп показав, що за значенням середнього екологічного індексу в 2027 році відповідатиме 3 категорії, II клас - гарний стан. Прогноз екологічного стану р. Уди в с. Окоп показав, що за значенням максимального екологічного індексу в 2032 році відповідатиме 5 категорії (незадовільний стан), III клас - задовільний стан.

Відповідно до визначення екологічного індексу для р. Уди в с. Окоп найменші значення спостерігались у 2003, 2005, 2010 і 2012 роках. Відповідно до методики [12] визначено екологічні індекси для допустимих і цільових екологічних нормативів р. Уди в с. Окоп (табл. 1).

Таблиця 1. Екологічні індекси для допустимих і цільових екологічних нормативів для р. Уди в с. Окіп

\begin{tabular}{|c|c|c|c|c|c|c|c|c|}
\hline Норматив & $\mathrm{I}_{1}$ сер & $\mathrm{I}_{2}$ cep & $\mathrm{I}_{3}$ cep & Iеcep & $\mathrm{I}_{1}$ мax & $\mathrm{I}_{2}$ мax & $\mathrm{I}_{3}$ мах & Іемах \\
\hline ЕНд & 2,67 & 3,57 & 3,20 & 3,15 & 4,00 & 7,00 & 4,00 & 5,00 \\
\hline ЕНц & 1,67 & 3,00 & 1,60 & 2,09 & 2,00 & 7,00 & 2,00 & 3,67 \\
\hline
\end{tabular}

Пост спостереження за якісним станом р. Уди в смт. Пересічне $\epsilon$ також пунктом відбору проб гідрометеорологічної служби та Держводагентства. На цій ділянці русло річки звивисте, шириною близько 10 м, течія не досить швидка. Лівий берег положисто-горбкуватий, покритий луговою рослинністю; вище розташовані городи, житлові будівлі. Правий берег покритий деревною рослинністю. Береги, в основному, абразивні, дно не пологе; грунт - чорний мул, місцями - замулений пісок [15].

Визначено середній і максимальний екологічний індекс для річки Уди в смт. Пересічне за період з 1971 року по 2017 рік. Значення середнього екологічного індексу для річки Уди в смт. Пересічне за період з 1971 року по 2017 рік відповідає 3 і 4 категоріям та 2 і 3 класам якості (гарний і задовільний стан). Значення максимального екологічного індексу для річки Уди в смт. Пересічне за період 31971 року по 2017 рік відповідає 5 і 6 категоріям (незадовільний і поганий стан) та 3 і 4 класам якості (задовільний і поганий стан).

Прогноз екологічного стану р. Уди в смт. Пересічне показав, що за значенням середнього екологічного індексу в 2042 році відповідатиме 3 категорії, II клас - гарний стан. Прогноз екологічного стану р. Уди в смт. Пересічне показав, що за значенням максимального екологічного індексу в 2042 році відповідатиме 6 категорії (поганий стан), IV клас - поганий стан.

Відповідно до визначення екологічного індексу для р. Уди в смт. Пересічне найменші значення спостерігались у 1983, 1995, 1999 і 2004 роках.

Відповідно до методики [12] визначено екологічні індекси для допустимих і цільових екологічних нормативів р. Уди в смт. Пересічне (табл. 2).

Таблиця 2. Екологічні індекси для допустимих і цільових екологічних нормативів для р. Уди в смт. Пересічне

\begin{tabular}{|c|c|c|c|c|c|c|c|c|}
\hline Норматив & $\mathrm{I}_{1}$ сер & $\mathrm{I}_{2}$ cep & $\mathrm{I}_{3}$ cep & Iеcep & $\mathrm{I}_{1}$ мах & $\mathrm{I}_{2}$ мax & $\mathrm{I}_{3}$ мax & Іемах \\
\hline ЕНд & 3,00 & 4,75 & 3,50 & 3,75 & 4,00 & 7,00 & 5,00 & 5,33 \\
\hline ЕНц & 1,50 & 3,50 & 1,75 & 2,25 & 2,00 & 5,00 & 3,00 & 3,33 \\
\hline
\end{tabular}

В с. Хорошево ширина річки Уди досягає 30 м, течія середня. Житлові будівлі до річки не прилягають; заплава заросла дерево-чагарниковою й трав'янистою рослинністю. Береги і дно не круті, відносно пологі. Грунт - переважно чорний рідкий мул, злегка промитий по центру русла [15].

Визначено середній і максимальний екологічний індекс для річки Уди в с. Хорошево за період з 1971 року по 2017 рік. Значення середнього екологічного індексу для річки Уди в с. Хорошево за період з 1971 року по 2017 рік відповідає 4 категорії (задовільний стан) та 3 класу якості (задовільний стан). Значення максимального екологічного індексу для річки Уди в с. Хорошево за період з 1971 року по 2017 рік відповідає 6 категорії (поганий стан) та 4 класу якості (поганий стан).

Прогноз екологічного стану р. Уди в с. Хорошево показав, що за значенням середнього екологічного індексу в 2041 році відповідатиме 4 категорії, III клас - задовільний стан. Прогноз екологічного стану р. Уди в с. Хорошево показав, що за значенням максимального екологічного індексу в 2041 році відповідатиме 7 категорії, V клас - дуже поганий стан. Відповідно до визначення екологічного індексу для р. Уди в с. Хорошево найменші значення спостерігались у 1971, 1993, 1997 і 2003 роках.

Відповідно до методики [12] визначено екологічні індекси для допустимих і цільових екологічних нормативів р. Уди в с. Хорошево (табл. 3). 
Таблиця 3. Екологічні індекси для допустимих і цільових екологічних нормативів для р. Уди в с. Хорошево

\begin{tabular}{|c|c|c|c|c|c|c|c|c|}
\hline Норматив & $\mathrm{I}_{1}$ сер & $\mathrm{I}_{2}$ сер & $\mathrm{I}_{3}$ сер & Iеcep & $\mathrm{I}_{1}$ мах & $\mathrm{I}_{2}$ мах & $\mathrm{I}_{3}$ мах & Iмах \\
\hline ЕНд & 4,50 & 4,00 & 3,50 & 4,00 & 5,00 & 7,00 & 5,00 & 5,67 \\
\hline ЕНц & 3,00 & 3,40 & 2,17 & 2,86 & 3,00 & 6,00 & 4,00 & 4,33 \\
\hline
\end{tabular}

Русло річки Уди в смт. Есхар досить широке (30-40 м), течія слабка. Береги пологі. Лівий рівнинний берег являє собою широку заплавну луку з окремими групами дерев, правий трохи крутіший; заріс дерево-чагарниковою рослинністю. Донні відкладення - досить потужний шар мулу, трохи промитий по фарватеру [15].

Визначено середній і максимальний екологічний індекс для річки Уди в смт. Есхар за період з 1964 року по 2017 рік. Значення середнього екологічного індексу для річки Уди в смт. Есхар за період з 1964 року по 2017 рік відповідає 4 категорії і 3 класу якості (задовільний стан). Значення максимального екологічного індексу для річки Уди за період з 1964 року по 2017 рік відповідає 6 категорії і 4 класу якості (поганий стан).

Прогноз екологічного стану р. Уди в смт. Есхар показав, що за значенням середнього екологічного індексу в 2042 році відповідатиме 4 категорії, III клас - задовільний стан. Прогноз екологічного стану р. Уди в смт. Есхар показав, що за значенням максимального екологічного індексу в 2042 році відповідатиме 7 категорії, V клас - дуже поганий стан. Відповідно до визначення екологічного індексу для р. Уди в смт. Есхар найменші значення спостерігались у 1964, 1972, 1990 і 1999 роках.

Відповідно до методики [12] визначено екологічні індекси для допустимих і цільових екологічних нормативів р. Уди в смт. Есхар (табл. 4).

Таблиця 4. Екологічні індекси для допустимих і цільових екологічних нормативів для р. Уди в смт. Есхар

\begin{tabular}{|c|c|c|c|c|c|c|c|c|}
\hline Норматив & $\mathrm{I}_{1}$ сер & $\mathrm{I}_{2}$ сер & $\mathrm{I}_{3}$ сер & Iеcep & $\mathrm{I}_{1}$ мах & $\mathrm{I}_{2}$ мах & $\mathrm{I}_{3}$ мах & Іемах \\
\hline ЕНд & 4,50 & 4,90 & 4,29 & 4,56 & 5,00 & 7,00 & 6,00 & 6,00 \\
\hline ЕНц & 2,50 & 3,50 & 2,86 & 2,95 & 4,00 & 7,00 & 6,00 & 5,67 \\
\hline
\end{tabular}

Рангування постів спостереження за якісним станом річки Уди в Харківській області за значенням екологічного індексу для допустимого екологічного нормативу показало, що найбільш забрудненою є ділянка в смт. Есхар (рис.1).

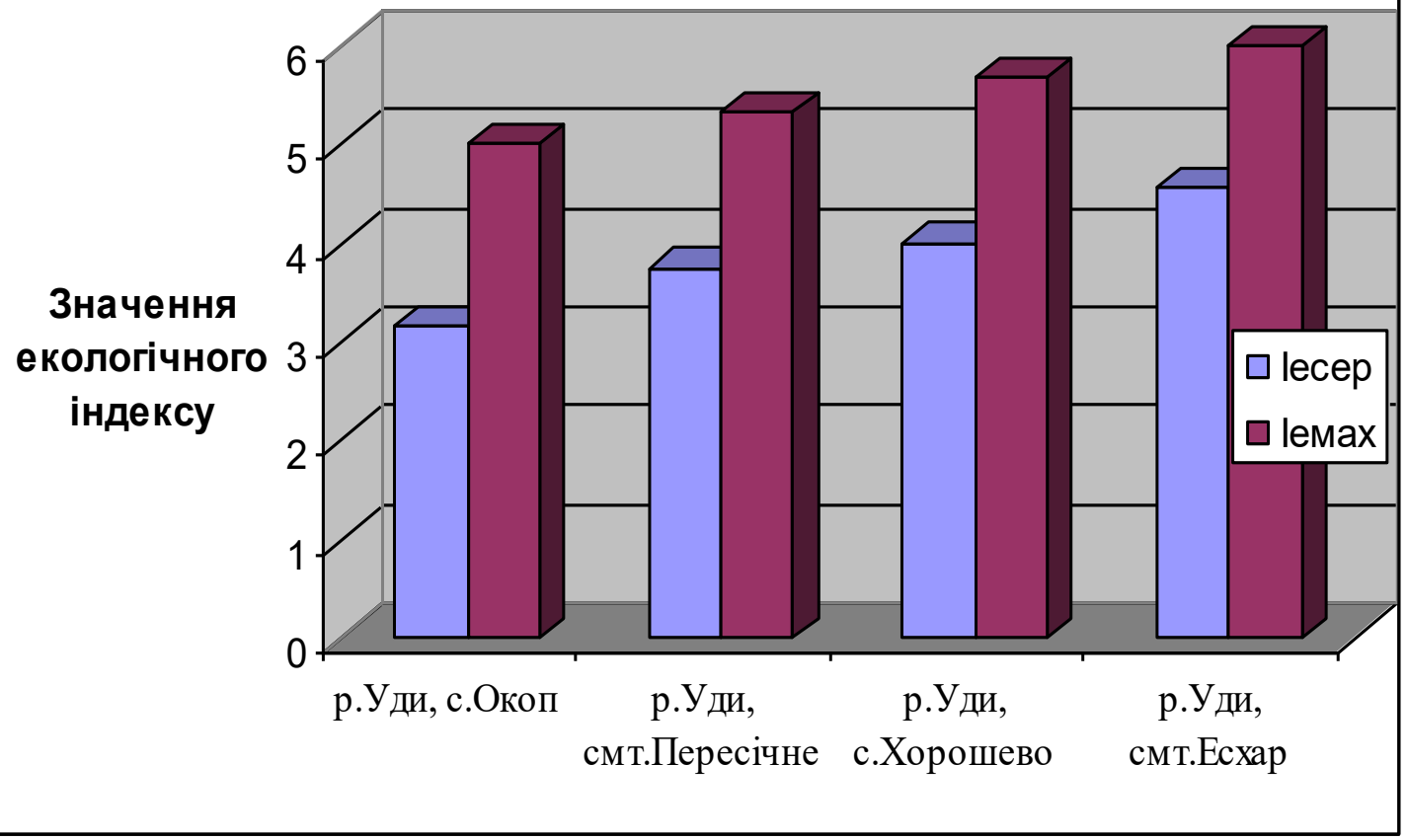

Рис. 1. Рангування постів спостереження за якісним станом річки Уди в Харківській області за значенням екологічного індексу для допустимого екологічного нормативу 
Необхідно відзначити, що значення максимального екологічного індексу для допустимого екологічного нормативу в с. Хорошево і смт. Есхар відповідає 6 категорії, 4 класу (поганий стан), а значення середнього екологічного індексу в смт. Есхар - 5 категорії (незадовільний стан).

Рангування постів спостереження за якісним станом річки Уди в Харківській області за значенням екологічного індексу для цільового екологічного нормативу показало, що найбільш забрудненою є також ділянка в смт. Есхар (рис.2).

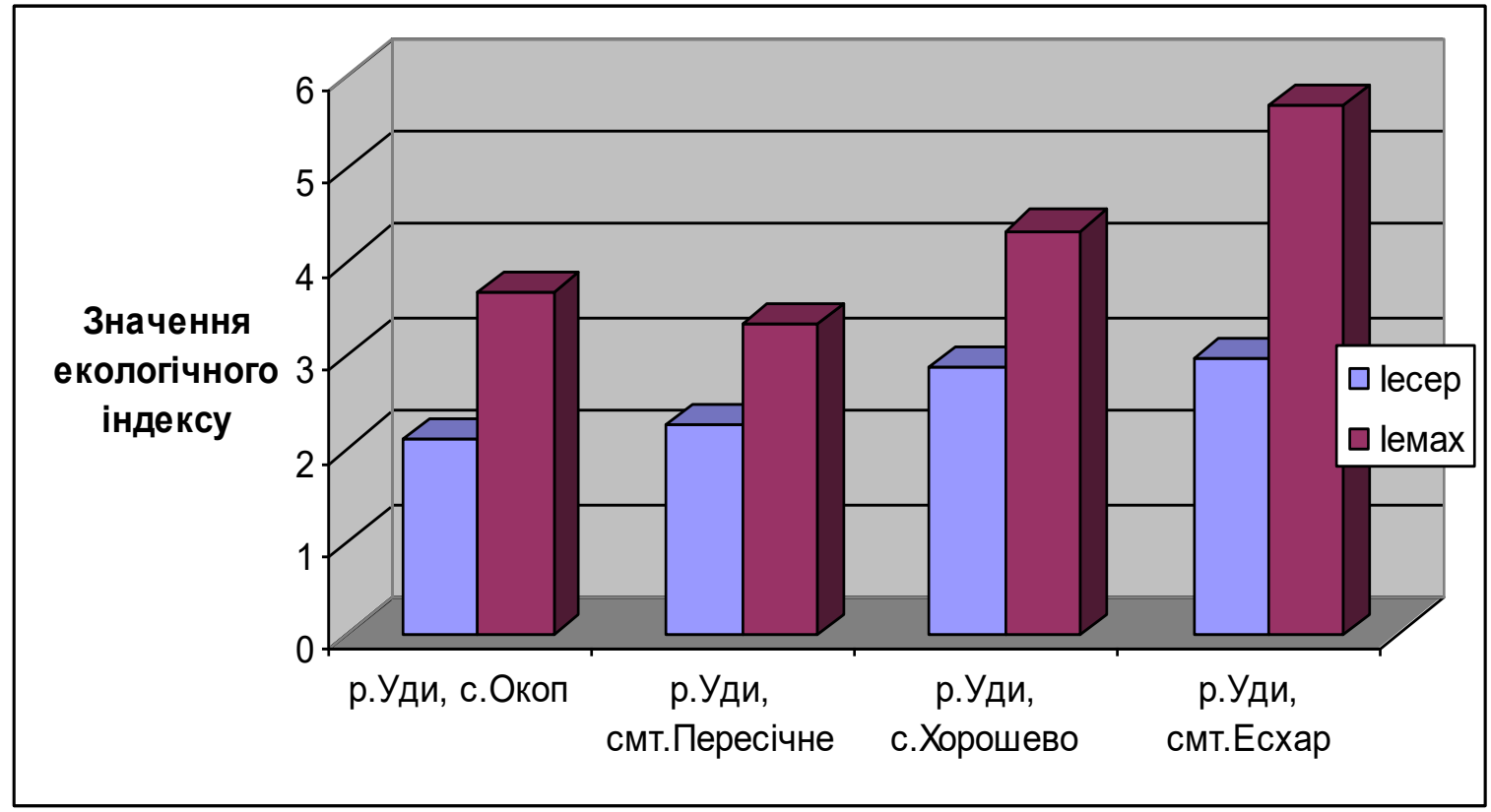

Рис. 2. Рангування постів спостереження за якісним станом річки Уди в Харківській області за значенням екологічного індексу для иільового екологічного нормативу

Значення середнього екологічного індексу для цільового екологічного нормативу річки Уди в Харківській області відповідає 2 категорії (дуже гарна якість) і 3 категорії 2 класу якості (гарний стан). Але за значенням максимального екологічного індексу для цільового екологічного нормативу річки Уди в Харківській області відповідає 3 категорії (гарна якість), 4 категорії (задовільна якість) і 5 категорії (незадовільна якість) 2 класу якості (гарний стан) і 3 класу якості (задовільний стан).

Порівняльний аналіз значень екологічних нормативів для річки Уди в Харківській області показав, що по деяким забруднюючим речовинам допустимі і навіть цільові екологічні нормативи перевищують значення рибогосподарських ГДК.

В річці Уди в с. Окоп допустимий екологічний норматив перевищує рибогосподарські ГДК по міді в 6,9 разів, по залізу загальному - 1,48 разів, по нафтопродуктам - в 1,38 разів, по сульфатам в 1,14 разів. Цільовий екологічний норматив перевищує рибогосподарські ГДК по міді в 1,06 разів.

В річці Уди в смт. Пересічне допустимий екологічний норматив перевищує рибогосподарські ГДК по нафтопродуктам в 2,43 разів, по БСК 5 - в 1,16 разів, по цинку ${ }^{2+}-$ в 1,13 разів, по сульфатам - в 1,04 разів. Цільовий екологічний норматив перевищує рибогосподарські ГДК по БСК 5 в 1,04 разів.

В річці Уди в с. Хорошево допустимий екологічний норматив перевищує рибогосподарські ГДК по азоту амонійному в 5,03 разів, нафтопродуктам - в 3,03 разів, по залізу загальному - в 2,36 разів, по марганцю - в 2,16 разів, БСК 5 - 1,74 разів, по сульфатам - в 1,65 разів, по цинку ${ }^{2+}-$ в 1,53 разів, Цільовий екологічний норматив перевищує рибогосподарські ГДК азоту амонійному в 3,26 разів, по нафтопродуктам - в 1,8 разів, по марганцю - в 1,5 разів.

В річці Уди в смт. Есхар допустимий екологічний норматив перевищує рибогосподарські ГДК по азоту амонійному в 7,41 разів, по цинку ${ }^{2+}-$ в 6,96 разів, по марганцю - в 4,06 разів, нафтопродуктам - в 3,15 разів, по сульфатам - в 1,85 разів, по фосфатам - в 1,65 разів, по БСК 5 - в 1,6 разів, по залізу загальному - в 1,32 разів. Цільовий екологічний норматив перевищує рибогосподарські ГДК по марганцю в 3,78 разів, по фосфатам - в 1,57 разів, по цинку ${ }^{2+}$ - в 1,5 разів, по сульфатам - в 1,22 разів, по БСК 5 - в 1,15 разів (табл. 5). 
Таблиця 5. Перевищення рибогосподарських ГДК (ГДКрг) допустимими екологічними нормативами (ЕНд) і цільовими екологічними нормативами (ЕНц) в річці Уди в смт. Есхар

\begin{tabular}{|c|c|c|c|c|}
\hline Назва показника & ЕНд & ЕНд/ГДКрг & ЕНц & ЕНц/ГДКрг \\
\hline Сульфати, мг/дм ${ }^{3}$ & 184,74 & 1,85 & 122,27 & 1,22 \\
\hline Азот амонійний, мг/дм ${ }^{3}$ & 3,71 & 7,41 & 0,34 & 0,67 \\
\hline Фосфати, мг/дм ${ }^{3}$ & 3,46 & 1,65 & 3,29 & 1,57 \\
\hline БСК 5, мг/дм ${ }^{3}$ & 4,80 & 1,60 & 3,45 & 1,15 \\
\hline Нафтопродукти, мг/дм³ & 0,16 & 3,15 & 0,02 & 0,40 \\
\hline Залізо загальне, мг/дм³ & 0,13 & 1,32 & 0,08 & 0,80 \\
\hline Цинк $\kappa^{2+}$, мг/дм ${ }^{3}$ & 0,07 & 6,96 & 0,015 & 1,50 \\
\hline Марганець, мг/дм³ & 0,04 & 4,06 & 0,038 & 3,78 \\
\hline
\end{tabular}

Необхідно відзначити, що допустимі і цільові екологічні нормативи визначались на основі спостереження за якісним станом річки Уди на протязі останніх 50 років і прогнозних моделей терміном на 20 - 25 років. Це означає, що дотримання рибогосподарських ГДК по вищезгаданим забруднюючим речовинам не є можливим.

Програмою управління якістю вод на період від п'яти до десяти років повинні передбачатися цільові показники із установленими строками їхнього досягнення по класах водокористування для конкретних водних об'єктів і заходи для їхнього виконання. Якщо аналіз економічної доцільності показує, що виконати деякі цільові показники у встановлений термін неможливо, вони повинні бути переглянуті убік зм'якшення вимог $[8,9,16]$.

Ітеративний процес планування якості вод покликаний знайти баланс між бажаними видами водокористування й цільовими показниками якості вод, з одного боку, і наявними фінансовими, технічними й кадровими ресурсами, з іншої. Ітеративний підхід до управління якістю поверхневих вод, який здійснюється в країнах $\mathrm{CC}$, передбачає поетапне досягнення цільових показників.

Для впровадження ітеративного підходу до управління водоохоронною діяльністю необхідним $є$ розробка науково обгрунтованих екологічних нормативів якості поверхневих вод з визначенням допустимих і цільових показників екологічного стану водних об'єктів.

Висновки. Оцінка екологічного стану річки Уди за значеннями екологічного індексу показала погіршення за довгостроковий період. Якісний стан річки Уди в Харківській області погіршується від кордону з Росією (с. Окоп) до гирла (смт. Есхар).

В роботі удосконалена методика встановлення екологічних нормативів якості поверхневих вод, яка спрямована на впровадження ітеративного підходу до управління якістю поверхневих вод в водоохоронну практику України та іiі адаптацію до екологічного законодавства країн ЄС.

Для визначення допустимих і цільових екологічних нормативів якості поверхневих вод пропонується застосування прогнозування методом Хольта - Уінтерса. Аналіз багаторічних спостережень за якісним станом поверхневих вод показав, що їх показники можуть різко змінюватися на протязі років, тому саме метод потрійного експонентного згладжування тимчасового ряду дозволяє робити як середньострокові, так і довгострокові прогнози, оскільки він здатний виявляти мікротренди у моменти часу, безпосередньо попередні прогнозним, і екстраполювати ці тренди на майбутнє.

Значення середнього екологічного індексу для цільового екологічного нормативу річки Уди в Харківській області відповідає 2 категорії (дуже гарна якість) і 3 категорії (гарна якість) 2 класу якості (гарний стан). За значенням максимального екологічного індексу для цільового екологічного нормативу річки Уди в Харківській області відповідає 3 категорії (гарна якість), 4 категорії (задовільна якість) і 5 категорії (незадовільна якість), 2 класу якості (гарний стан) і 3 класу якості (задовільний стан).

Ранжування постів спостереження за якісним станом річки Уди за значенням екологічного індексу для допустимого і цільового екологічного нормативу показало, що найбільш забрудненою є ділянка в смт. Есхар.

Розрахунки показали, що необхідним є першочергове впровадження природоохоронних заходів на ділянці річки Уди в смт. Есхар на основі аналізу впливу природних і антропогенних чинників на водну екосистему 3 урахуванням оцінки раціональності господарського використання водозбірної площі. 


\section{ЛІТЕРАТУРА}

1. Закон України "Про охорону навколишнього природного середовища". - К.: Україна. - 1991. - 59c

2. Водний Кодекс України Видання газети "Голос України”, 1995 .- 15 с

3. Концепція екологічного нормування. - К.: Мінекобезпеки України, 1997. - 20 с

4. EU Water Framework Directive 2000/60/EC. [Електронній ресурс]. - Режим доступу: http://www.ab.gov.tr/files/SEPB/cevrefaslidokumanlar/2000_60_atsayilisucercevedirektifi.pdf

5. Task Force for the Implementation of the Environmental Action Programme for Central and Eastern Europe, Caucasus and Central Asia Regulatory Environmental Programme Implementation Network / Organisation for Economic Co-operation and Development / ENV/EPOC/EAP/REPIN(2011)1/FINAL 7 - p.53

6. Васенко О.Г., Коробкова Г.В. Загальні принципи визначення екологічних нормативів якості поверхневих вод// Екологічна безпека: проблеми і шляхи вирішення: VII Міжнародна наук.-практ. конф., 12-16 вересня 2011 р., м. Алушта, АР Крим, Україна : Зб. наук. ст. У 2-х т. Т. 1 УкрНДІЕП. - Х.: Райдер, 2011, 332 с. - с.228-233

7. Коробкова Г.В. Методи екологічного нормування у адміністративно-басейновому управлінні водоохоронною діяльністю / Г.В. Коробкова // Екологічна безпека: проблеми і шляхи вирішення: зб. наук. ст. ХІ Міжнар. наук. -практ. конф., (м.Харків, 7-11 вересня 2015), УкрНДІЕП. - Х.: Райдер, 2015. - С. 131-134

8. Васенко О.Г., Рибалова О.В., Коробкова Г.В. Экологическое нормирование качества поверхностных вод с учетом региональных особенностей. Гідрологія, гідрохімія і гідроекологія. - 2017. - Т1 (44). - С. 21-33

9. Васенко О.Г., Рибалова О.В., Коробкова Г.В. Визначення екологічних нормативів якості поверхневих вод 3 урахуванням прогнозних моделей та регіональних особливостей . East Europian Scientific Journal. - 2016. - № 8 (12). Volume 3. - C. 5-13

10. Васенко О.Г. Комплексне планування та управління водними ресурсами [Текст] / О.Г. Васенко, Г.А. Верніченко. - Київ : Інститут географії НАН України, 2001. - 367 с

11. Романенко В.Д., Жукинский В.Н., Оксиюк О.П. Методологические предпосылки для установления и использования экологических нормативов качества поверхностных вод // Гидробиол. журнал, T. 35, № 3, 1999. - C. 3-14

12. Методика екологічної оцінки якості поверхневих вод за відповідними категоріями / [Романенко В. Д., Жукинський В. М., Оксіюк О. П. та ін. ] - К. : Символ-Т, 1998. - 28 с

13. Методика екологічної оцінки якості поверхневих вод за відповідними категоріями [Електронній ресурс]: проект/А.В.Гриценко, О.Г.Васенко, Г.А.Верніченко [та ін.] - Режим доступу: http://www.niiep.kharkov.ua/sites/default/files/metodika_2012_14_0. doc]

14. Рибалова О.В., Коробкова Г.В. Застосування методу Хольта-Уінтерса для прогнозування якісного стану поверхневих вод. Проблеми техногенно-екологічної безпеки: освіта, наука, практика: збірник матеріалів Всеукраїнської науково-практичної конференції. - Харків: НУЦЗУ, 2016. - С.201-202

15. Комплексні експедиційні дослідження екологічного стану водних об'єктів басейну р.Уди (суббасейну р.Сіверський Донець) / О.Г. Васенко, М.Л. Лунгу, Ю.А. Ільєвськая, О.В. Климов та ін. /Під ред. О.Г. Васенко. - Х.: ВД «Райдер», 2006. - 156с

16. Рибалова О.В. Ітеративний підхід до управління якістю поверхневих вод. Проблеми техногенноекологічної безпеки: освіта, наука, практика: збірник матеріалів Всеукраїнської науково-практичної конференції. - Харків: НУЦЗУ, 2016. - С.199 -201 